\title{
A SOBERANIA ENERGÉTICA EM FACE DA ORDEM ECONÔMICA CONSTITUCIONAL E O ACORDO DE PARIS: A POLÍTICA ENERGÉTICA NACIONAL COMO INSTRUMENTO DE DESENVOLVIMENTO SUSTENTÁVEL
}

\author{
ENERGY SOVEREIGNTY IN LIGHT OF THE CONSTITUTIONAL ECONOMIC ORDER \\ AND THE PARIS AGREEMENT: NATIONAL ENERGY POLICY AS AN INSTRUMENT \\ FOR SUSTAINABLE DEVELOPMENT
}

\begin{abstract}
LA SOBERANÍA ENERGÉTICA ANTE EL ORDEN ECONÓMICO CONSTITUCIONAL YEL ACUERDO DE PARÍS: LA POLÍTICA ENERGÉTICA NACIONAL COMO INSTRUMENTO Licença CC BY:

DE DESARROLLO SOSTENIBLE
\end{abstract}

Artigo distribuído sob os termos Creative Commons, permite uso e distribuição irrestrita em qualquer meio desde que o autor credite a fonte original.

\section{Celso Antonio Pacheco Fiorillo ${ }^{1}$}

\author{
Renata Marques Ferreira ${ }^{2}$
}

É o primeiro professor Livre-Docente em Direito Ambiental do Brasil, sendo também Doutor e Mestre em Direito das Relações Sociais. Director Académico do Congresso de Derecho Ambiental Contemporáneo España/Brasil-Universidade de Salamanca (Espanha) e Miembro del Grupo de Estudios Procesales de la Universidad de Salamanca-Grupo de Investigación Reconocido IUDICIUM (ESPANHA). Professor convidado visitante da Escola Superior de Tecnologia do Instituto Politécnico de Tomar (Portugal) e Professor Visitante/Pesquisador da Facoltà di Giurisprudenza della Seconda Università Degli Studi di Napoli (Itália). Professor Permanente do Programa de Mestrado em Direito da UNINOVE-SP (Brasil). Líder do Grupo de Pesquisa do CNPq Tutela Jurídica das Empresas em face do Direito Ambiental Constitucional UNINOVE e Pesquisador dos Grupos de Pesquisa do CNPq Sustentabilidade, Impacto e Gestão Ambiental - UFPB, Novos Direitos - UFSCAR e Responsabilidade e Funcionalização do Direito UNINOVE. Foi Presidente da Comissão Permanente do Meio Ambiente da OAB/SP (por duas vezes, 2013/2015 e 2016/2018) bem como, no mesmo período, Presidente do Comitê de Defesa da Dignidade da Pessoa Humana no âmbito do Meio Ambiente Digital da Comissão de Direitos Humanos, representante da OAB/SP no Conselho Gestor do Fundo Estadual de Defesa dos Interesses Difusos da Secretaria da Justiça, do Fundo Estadual para Prevenção e Remediação de Áreas Contaminadas e do Comitê da Bacia Hidrográfica do Tietê. Elaborador, coordenador e professor do Curso de Especialização de Direito Ambiental da Escola Superior de Advocacia da OAB/SP. Chanceler da Academia de Direitos Humanos. Titular da cadeira 43, patrono Sylvio Marcondes da Academia Paulista de Direito. Assessor científico da FAPESP, parecerista ad hoc do Centro de Estudos Judiciários do Conselho da Justiça Federal, professor efetivo da Escola de Magistratura do TRF da $3^{a}$ Região e professor da Escola Nacional de Formação e Aperfeiçoamento de Magistrados Enfam. Professor convidado do Curso de Especialização em Engenharia Sanitária Ambiental da Universidade Mackenzie. Professor da Escola Superior da Magistratura Federal do RS. Elaborador/coordenador/professor do Curso de Pós-Graduação em Direito Ambiental da Escola Paulista da Magistratura - EPM. Professor do MBA Direito Empresarial/FUNDACE-USP. Integrante do Consejo Científico da Revista Americana de Urbanismo (Espanha) e membro convidado do Conselho Editorial da Revista Aranzadi de Derecho Ambiental (Espanha). Integrante do Comitato Scientifico do periódico Mater iali e S tudi di Diritto Pubblico da Seconda Università Degli Studi Di Napoli, do Consejo Científico de la colección de Estudios Jurídicos de Ediciones Universidade de Salamanca, do Consejo Científico da Revista Americana de Urbanismo (Madrid), bem como do Comitê Científico do Instituto Internacional de Estudos e Pesquisas sobre os Bens Comuns, com sede em Paris/França (Institut International d'Etudes et de Recherches sur les Biens Communs) e Roma/Itália (Istituto Internazionale di Ricerca sui Beni Comuni). Membro da UCN, the International Union for Conservation of Nature

Pós-Doutora pela Universidade de São Paulo (Escola Politécnica-USP) e Doutora em Direito das Relações Sociais (subárea de Direitos Difusos e Coletivos - Direito Ambiental) pela Pontifícia Universidade Católica de São Paulo. Mestre em Direito das Relações Sociais (subárea de Direitos Difusos e Coletivos - Direito Ambiental Tributário) pela Pontifícia Universidade Católica de São Paulo. Professora convidada da Escola Superior de Advocacia da Ordem dos Advogados do Brasil - Seção de São Paulo (ESA-OAB/SP). Foi coordenadora do Grupo de Trabalho de Tutela Jurídica da Saúde Ambiental, bem como de Tutela Jurídica da Governança Corporativa Sustentável da Comissão do Meio Ambiente da Ordem dos Advogados do Brasil-Seção de São Paulo (OAB/SP). Pesquisadora do grupo de pesquisas Novos Direitos da Universidade Federal de São Carlos - UFSCar. Parecerista da Revista de Direito da Cidade Qualis A1-UERJ e da Revista Quaestio luris Qualis A2 - UERJ. Professora convidada do Curso de Especialização em Saneamento Ambiental da Universidade Mackenzie. Professora de Direito Ambiental Tributário do curso de extensão universitária da Escola Paulista da Magistratura. Coordenadora do curso de Direito das Faculdades Integradas Rio Branco - Unidade Granja Viana, Professora Doutora das Faculdades Integradas Rio Branco (Fundação Rotary) - Unidade Granja Viana. Coordenadora Científica do periódico Direito Ambiental Contemporâneo/Editora Saraiva. 
Resumo: O denominado Acordo de Paris, aprovado em nosso País pelo Decreto Legislativo 140/16, tem sua efetividade jurídica concretamente condicionada ao que estabelecem os fundamentos constitucionais da política energética nacional brasileira interpretada em face dos Princípios Fundamentais (soberania, independência nacional e dignidade da pessoa humana), bem como dos princípios Gerais da Atividade Econômica de nossa Lei Maior (particularmente a da defesa do meio ambiente), assim como no plano infraconstitucional, ao regramento normativo fixado pela Política Nacional sobre Mudança do Clima (lei 12187/09) e, principalmente, em face de seu objetivo, ao conteúdo normativo estruturado pela Política Energética Nacional (Lei 9.478/97). Referida interpretação, ao garantir a segurança energética necessária para o desenvolvimento do Brasil em harmonia com as balizas normativas estabelecidas pelo direito ambiental constitucional e em proveito da dignidade dos brasileiros e dos estrangeiros residentes no País, se destaca como relevante instrumento de desenvolvimento sustentável destinado a erradicar a pobreza e a marginalização e reduzir as desigualdades sociais e regionais no Brasil.

Palavras-chave: Acordo de Paris. Soberania. Independência Nacional. Política Nacional sobre Mudança do Clima. Política Energética Brasileira. Direito Ambiental Constitucional. Desenvolvimento Nacional. Petróleo. Bens ambientais.

Abstract:The legal effectiveness of the so-called Paris Agreement, approved in our country by Legislative Decree 140/16, was concretely qualified by the constitutional foundations of the Brazilian national energy policy, interpreted in light of the Fundamental Principles (sovereignty, national independence and dignity of the human person), as well as the general principles of the Economic Activity of our Major Law (particularly the protection of the environment) as well as the infraconstitutional plan, the normative rule established by the National Policy on Climate Change (Law 12187/09) and, in view of its objective, the normative content structured by the National Energy Policy (Law 9.478/97). This interpretation, which guarantees the energy security necessary for the development of Brazil in keeping with the regulatory framework established by constitutional environmental law, and in favor of the dignity of Brazilians and foreigners residing in the country, is an important instrument for sustainable development, aimed at eradicating poverty and marginalization and reducing social and regional inequalities in Brazil.

Keywords: Paris Agreement. Sovereignty. National Independence. National Policy on Climate Change. Brazilian Energy Policy. Constitutional Environmental Law. National Development. Petroleum. Environmental goods.

Resumen: El denominado Acuerdo de París, aprobado en nuestro País por el Decreto Legislativo 140/16, tiene su efectividad jurídica concretamente condicionada al que establecen los fundamentos constitucionales de la política energética nacional brasileña interpretada ante los Principios Fundamentales (soberanía, independencia nacional y dignidad de la persona humana), bien como de los principios Generales de la Actividad Económica de nuestra Ley Mayor (particularmente a la defensa del medio ambiente), así como en el plano infraconstitucional, al reglamento normativo fijado por la Política Nacional sobre Cambios del Clima (ley 12187/09) y, principalmente, ante su objetivo, al contenido normativo estructurado por la Política Energética Nacional (Ley 9.478/97). Referida interpretación, al garantizar la seguridad energética necesaria para el desarrollo del Brasil en harmonía con las balizas normativas establecidas por el derecho ambiental constitucional y en provecho de la dignidad de los brasileños y de los extranjeros residentes en el País, se destaca como relevante instrumento de desarrollo sostenible destinado a erradicar la pobreza y la marginación y reducir las desigualdades sociales y regionales en Brasil.

Palabras clave: Acuerdo de París. Soberanía. Independencia Nacional. Política Nacional sobre Cambios del Clima. Política Energética Brasileña. Derecho Ambiental Constitucional. Desarrollo Nacional. Petróleo. Bienes ambientales. 


\section{INTRODUÇÃO}

O Acordo de Paris, sob a Convenção-Quadro das Nações Unidas sobre Mudança do Clima (UNFCCC), adotado em Paris em 12 de dezembro de 2015 e assinado em Nova lorque em 22 de abril de $2016^{3}$, foi aprovado em nosso país, conforme estabelecido pelo Decreto Legislativo 140 de $2016^{45}$, ingressando em nosso ordenamento jurídico como atos normativos infraconstitucionais, conforme ensina o Ministro Alexandre de Moraes (MORAES, 2011).

Indicando amplo conjunto de dispositivos ${ }^{6}, 0$ aludido Acordo, que ao pretender fortalecer a resposta global à ameaça das mudanças climáticas procura estabelecer medidas de redução de emissão de dióxido de carbono a partir de 2020, afetando diretamente as atividades econômicas vinculadas ao uso de fontes de energia (renováveis e não renováveis) por parte dos diferentes participantes do referido pacto, deve, todavia, ser necessariamente interpretado não só em face da superior orientação de nossa Lei Maior, vez que, conforme ensina José Afonso da Silva, "no sistema brasileiro todos esses ajustes internacionais são hierarquicamente inferiores à Constituição"7, como particularmente em decorrência de nossa legislação infraconstitucional relacionada ao seu conteúdo.

Assim, sobre esse último aspecto, cabe desde logo destacar - independentemente dos parâmetros constitucionais que serão oportunamente analisados - que os princípios dispostos na Lei 12.187/2009, que instituiu no Brasil a Política Nacional sobre Mudança do Clima, já se adequavam substancialmente ao referido Acordo de Paris, sendo certo que em referida norma jurídica ocorreu VETO a diretrizes que pretendiam estar focadas no abandono do uso de combustíveis fósseis, bem como aos critérios destinados a estabelecer formas de substituição dos combustíveis fósseis na matriz energética brasileira, vez que não estariam adequadamente concatenadas "com as necessidades energéticas do País", o que poderia "fragilizar a confiabilidade

3 Com o argumento de que necessitava ajudar as indústrias de petróleo e carvão de seu país, o presidente dos Estados Unidos, Donald Trump, em 1 de junho de 2017, anunciou que o país deixaria toda sua participação no Acordo de Paris sobre mudanças climáticas firmado em 2015. https://www.bbc.com/news/world-us-canada-40127326, acesso em 02 de janeiro de 2019.

4 DECRETO LEGISLATIVO № 140, DE 2016. Aprova o texto do Acordo de Paris sob a Convenção-Quadro das Nações Unidas sobre Mudança do Clima - UNFCCC, celebrado em Paris, em 12 de dezembro de 2015, e assinado em Nova lorque, em 22 de abril de 2016. O Congresso Nacional decreta: Art. $1^{\circ}$ Fica aprovado o texto do Acordo de Paris sob a Convenção-Quadro das Nações Unidas sobre Mudança do Clima UNFCCC, celebrado em Paris, em 12 de dezembro de 2015, e assinado em Nova York, em 22 de abril de 2016. Parágrafo único. Nos termos do inciso I do art. 49 da Constituição Federal, ficam sujeitos à aprovação do Congresso Nacional quaisquer atos que possam resultar em revisão do referido Acordo, bem como quaisquer ajustes complementares que acarretem encargos ou compromissos gravosos ao patrimônio nacional. Art. $2^{\circ}$ Este Decreto Legislativo entra em vigor na data de sua publicação. Senado Federal, em 16 de agosto de 2016. Senador RENAN CALHEIROS, Presidente do Senado Federal.

5 Acordo de Paris http://www2.camara.leg.br/legin/fed/decleg/2016/decretolegislativo-140-16-agosto-2016-783505-acordo-150960-pl.html acesso em 02 de janeiro de 2019

6 A estrutura do Acordo de Paris pode ser dividida em: objetivo (art. 2); áreas de ação - mitigação (art. 3-6), adaptação e perdas e danos (art. 7-8); meios de implementação - financiamento (art. 9), tecnologia (art. 10), capacitação (art. 11) e educação (art.12); transparência (art.13); cumprimento - avaliação global (art.14), facilitação e conformidade (art. 15); arcabouço institucional (art. 16-19); e dispositivos gerais (art. 2029).

7 SILVA, José Afonso. Comentário Contextual à Constituição. $7^{\text {a }}$ ed. São Paulo: Malheiros, 2010. 
e a segurança do sistema energético nacional"8. Igualmente, destacava o VETO que as diretrizes do dispositivo afastado (Art.10) desconsiderava, por exemplo, "a possibilidade de utilização de energia produzida a partir de centrais hidrelétricas, fonte que contribui sobremaneira para que a matriz energética brasileira esteja entre as mais limpas do mundo, além de constituir grande parte da geração de energia elétrica do País".

Destarte, ao contrário do que pretendem impor alguns setores comprometidos com valores outros, o denominado Acordo de Paris tem sua efetividade jurídica em nosso País concretamente condicionada aos Princípios Fundamentais, bem como aos Princípios Gerais da Atividade Econômica de nossa Lei Maior (particularmente o da defesa do meio ambiente), assim como ao que determina no plano constitucional e infraconstitucional não só a Política Nacional sobre Mudança do Clima (Lei 12.187/2009), mas, principalmente, em face de seu objetivo, ao conteúdo normativo estruturado pela Política Energética Nacional (Lei 9.478/97), visando garantir a segurança energética necessária para o desenvolvimento do Brasil em harmonia, por força de seu conteúdo, com as balizas normativas estabelecidas pelo direito ambiental constitucional.

Senão, veja-se.

8 Presidência da República. Casa Civil. Subchefia para Assuntos Jurídicos. MENSAGEM No 1.123, DE 29 DE DEZEMBRO DE 2009. Senhor Presidente do Senado Federal, Comunico a Vossa Excelência que, nos termos do $\S 1^{\circ}$ do art. 66 da Constituição, decidi vetar parcialmente, por contrariedade ao interesse público e inconstitucionalidade, o Projeto de Lei no 18, de 2007 (no 283/09 no Senado Federal), que "Institui a Política Nacional sobre Mudança do Clima - PNMC e dá outras providências". Ouvidos os Ministérios da Fazenda, do Planejamento, Orçamento e Gestão e a Advocacia-Geral da União, manifestaram-se pelo veto ao seguinte dispositivo: Inciso VI do art. $3^{\circ}$, VI - o dispêndio público com as ações de enfrentamento das alterações climáticas não sofrerá contingenciamento de nenhuma espécie durante a execução orçamentária". Razões do veto: "O dispositivo carreia comando com mandamentos genéricos sobre finanças públicas, matéria afeta a Lei Complementar, conforme previsto no art. 163, I, da Constituição Federal. Ademais, o dispositivo contraria o princípio presente na Lei de Responsabilidade Fiscal de que as prioridades de cada exercício devam ser definidas por meio das leis de diretrizes orçamentárias". Ouvido, também, o Ministério de Minas e Energia manifestou-se pelo veto aos seguintes dispositivos: Inciso III do art. $4^{\circ}$. III - ao estímulo ao desenvolvimento e ao uso de tecnologias limpas e ao paulatino abandono do uso de fontes energéticas que utilizem combustíveis fósseis; Razões do veto: "A atual política energética do País já tem priorizado a utilização de fontes de energia renováveis em sua matriz e obtido avanços amplamente reconhecidos no uso de tecnologias limpas. Uma das balizas dessa política é o aproveitamento racional dos vários recursos energéticos disponíveis, o que torna inadequada uma diretriz focada no abandono do uso de combustíveis fósseis. A estratégia para o setor deve atender aos princípios e objetivos estabelecidos pela Lei $n^{\circ}$ 9.478, de 6 de agosto de 1997, que congrega a proteção ao meio ambiente a outros valores relevantes para a política e a segurança energéticas". "Art. 10. A substituição gradativa dos combustíveis fósseis, como instrumento de ação governamental no âmbito da PNMC, consiste no incentivo ao desenvolvimento de energias renováveis e no aumento progressivo de sua participação na matriz energética brasileira, em substituição aos combustíveis fósseis. Parágrafo único. A substituição gradativa dos combustiveis fósseis será obtida mediante: I - o aumento gradativo da participação da energia elétrica produzida por empreendimentos de Produtores Independentes Autônomos, concebidos com base nas fontes eólicas de geração de energia, nas pequenas centrais hidrelétricas e de biomassa, no Sistema Elétrico Interligado Nacional; II - o incentivo à produção de biodiesel, preferencialmente a partir de unidades produtoras de agricultura familiar e de cooperativas ou associações de pequenos produtores, e ao seu uso progressivo em substituição ao óleo diesel derivado de petróleo, particularmente no setor de transportes; III - o estímulo à produção de energia a partir das fontes solar, eólica, termal, da biomassa e da co-geração, e pelo aproveitamento do potencial hidráulico de sistemas isolados de pequeno porte; IV - o incentivo à utilização da energia térmica solar em sistemas para aquecimento de água, para a redução do consumo doméstico de eletricidade e industrial, em especial nas localidades em que a produção desta advenha de usinas termelétricas movidas a combustíveis fósseis; $V$ - a promoção, por organismos públicos de Pesquisa e Desenvolvimento científico-tecnológico, de estudos e pesquisas científicas e de inovação tecnológica acerca das fontes renováveis de energia; VI - a promoção da educação ambiental, formal e não formal, a respeito das vantagens e desvantagens e da crescente necessidade de utilização de fontes renováveis de energia em substituição aos combustíveis fósseis; VII - o tratamento tributário diferenciado dos equipamentos destinados à geração de energia por fontes renováveis; VIII - o incentivo à produção de etanol e ao aumento das porcentagens de seu uso na mistura da gasolina; IX - o incentivo à produção de carvão vegetal a partir de florestas plantadas." Razões do veto: "O dispositivo pretende indicar as formas de substituição dos combustíveis fósseis na matriz energética brasileira. Essa indicação, entretanto, não está adequadamente concatenada com as necessidades energéticas do País, o que pode fragilizar a confiabilidade e a segurança do sistema energético nacional. Há que se destacar, por exemplo, que as diretrizes do dispositivo desconsideram a possibilidade de utilização de energia produzida a partir de centrais hidrelétricas, fonte que contribui sobremaneira para que a matriz energética brasileira esteja entre as mais limpas do mundo, além de constituir grande parte da geração de energia elétrica do País. Assim, as diretrizes da PNMC e da Política Energética Nacional deverão ser harmonizadas de forma a proteger o meio ambiente e, ao mesmo tempo, garantir a segurança energética necessária para o desenvolvimento do País". Essas, Senhor Presidente, as razões que me levaram a vetar os dispositivos acima mencionados do projeto em causa, as quais ora submeto à elevada apreciação dos Senhores Membros do Congresso Nacional. Este texto não substitui o publicado no DOU de 30.12.2009. 


\section{A SOBERANIA E OS FUNDAMENTOS CONSTITUCIONAIS DA POLÍTICA ENERGÉTICA NACIONAL BRASILEIRA: A TUTELA JURÍDICA DO PETRÓLEO E DO CARVÃO EM FACE DA SUPERIOR ORIENTAÇÃO NORMATIVA DELIMITADA PELA CONSTITUIÇÃO FEDERAL E A SUA RELEVÂNCIA NO ÂMBITO DAS ATIVIDADES ECONÔMICAS EM NOSSO PAÍS.}

Historicamente o aproveitamento racional dos vários recursos energéticos disponíveis em nosso País ${ }^{9}$ (particularmente o petróleo) sempre levou o legislador a procurar estabelecer no plano constitucional e infraconstitucional uma equilibrada política energética nacional estruturada particularmente em face da relevância econômica gerada por referidos recursos em proveito dos brasileiros e dos estrangeiros residentes no País, associando o tema à própria soberania ${ }^{10}$. Daí, o Livro Branco de Defesa Nacional ${ }^{11}$, ao esclarecer as atividades de defesa do País ${ }^{12}$, no sentido de exercer completa e exclusiva soberania ${ }^{1314}$ sobre seu território, seu mar territorial e o espaço aéreo sobrejacente, não aceitando nenhuma forma de ingerência externa em suas decisões, destacar explicitamente a condição brasileira de grande produtor de energia renovável e não renovável como patrimônio a exigir referida defesa.

Com efeito.

Possuidor tanto de fontes de energia não renovável (petróleo, carvão mineral, gás natural e nuclear) como de fontes de energia renovável (eólica, hidrelétrica, solar), o Brasil, no que se refere

9 As principais fontes de energia do Brasil, atualmente, são: petróleo (principal fonte de energia brasileira é utilizado para a geração de energia para veículos motores, por meio da produção de gasolina, óleo diesel, querosene, bem como é responsável pelo abastecimento de usinas termoelétricas), energia hidroelétrica, carvão mineral e biocombustíveis, além de algumas outras utilizadas em menor escala, como gás natural e energia nuclear.

10 A respeito do tema, vide de forma detalhada FIORILLO, Celso Antonio Pacheco; FERREIRA, Renata Marques. Curso de direito da energia Tutela jurídica da água, do petróleo, do biocombustível, dos combustíveis nucleares, do vento e do sol. 3. ed. São Paulo: Ed. Saraiva, 2015.

11 A Lei Complementar 97/1999, modificada pela Lei Complementar 136/2010, estabeleceu, em seu Artigo $9^{\circ}$, parágrafo. $3^{\circ}$, a obrigatoriedade de o Poder Executivo apresentar ao Congresso Nacional, na primeira metade da sessão legislativa ordinária de 2012, a primeira versão do Livro Branco de Defesa Nacional.

12 "A política de defesa determina a capacidade estatal de oferecer proteção ao povo brasileiro e de garantir a não ingerência externa em seu território e em suas águas jurisdicionais, inclusive o espaço aéreo sobrejacente, o leito marinho e o subsolo. A soberania da Nação, sua inserção econômica competitiva e seu desenvolvimento pleno pressupõe capacidade de defesa condizente com as potencialidades e aspirações do País". https://www.defesa.gov.br/arquivos/2012/mes07/lbdn.pdf, acesso em 02 de janeiro de 2019.

13 "A soberania é o primeiro fundamento citado no art. $1^{\circ}$ da Constituição Federal brasileira. A soberania é inalienável, indivisível e imprescritível. Deve ser exercida pela vontade geral e ser preservada em nome das futuras gerações e da prosperidade do País. Trata-se de uma ordem suprema, que não deve se submeter a outra ordem". https://www.defesa.gov.br/arquivos/2012/mes07/lbdn.pdf, acesso em: 02 de janeiro de 2019.

14 Conforme esclarece o Livro Branco de Defesa Nacional, "O Brasil guia sua atuação na área ambiental pelo "Princípio 2 [18] da Declaração do Rio de Janeiro sobre Meio Ambiente e Desenvolvimento, adotada por ocasião da Conferência das Nações Unidas sobre Ambiente e Desenvolvimento Sustentável [19] (CNUMAD, ou Rio-92), o qual reafirma o direito soberano de cada nação de explorar seus recursos naturais segundo suas próprias políticas ambientais e de desenvolvimento".

Princípio 2: "Os Estados, de conformidade com a Carta das Nações Unidas e com os princípios de Direito Internacional, têm o direito soberano de explorar seus próprios recursos segundo suas próprias políticas de meio ambiente e desenvolvimento, e a responsabilidade de assegurar que atividades sob sua jurisdição ou controle não causem danos ao meio ambiente de outros Estados ou de áreas além dos limites da jurisdição nacional". https://www.defesa.gov.br/arquivos/2012/mes07/lbdn.pdf, acesso em: 02 de janeiro de 2019. 


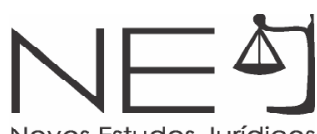

Novos Estudos Jurídicos

às fontes de energia mais utilizadas no mundo ${ }^{15}$, se destaca tanto nas reservas (150 do mundo) ${ }^{16}$ como na produção ( $9^{\circ}$ do mundo $)^{17}$ e na exportação de petróleo $\left(15^{\circ} \text { do mundo }\right)^{18}$, assim como nas reservas ${ }^{19}$ de carvão ( $15^{\circ}$ do mundo), a saber, nosso País se destaca nas reservas das duas fontes de energia mais utilizadas do mundo (fontes que correspondem a aproximadamente $60 \%$ do total) em face de uma realidade que nos coloca em uma posição estratégica frente à grande demanda de energia mundial ${ }^{20}$.

Destarte, embora não renováveis (finitas/esgotáveis), o petróleo e o carvão são fontes abundantes em nosso País, possuindo um rendimento energético elevado e preços atrativos, gerando importantes ganhos econômicos para o Brasil ${ }^{21,22}$, além de empregos e possuindo infraestrutura construída para geração e distribuição (usinas, dutos, ferrovias e rodovias) ${ }^{23}$.

Daí ainda que exista, conforme observam Mauricio T. Tolmasquim, Amilcar Guerreiro e Ricardo Gorini24, "uma clara tendência de diversificação da matriz energética brasileira, podemos observar no gráfico adiante indicado (Gráfico 2 - Evolução da Estrutura da oferta de energia) que em 1970 apenas duas fontes de energia, petróleo e lenha, respondiam por 78\% do consumo, enquanto em 2000 três fontes correspondiam a 74\% do consumo: além de petróleo e lenha, a energia hidráulica. Projeta-se para 2030 uma situação em que quatro fontes serão necessárias para satisfazer 77\% do consumo: além de petróleo e energia hidráulica, cana-de-açúcar e gás natural — com redução da importância relativa da lenha."

15 As fontes de energia mais utilizadas no mundo (matriz energética mundial) são: $1^{\circ}$ - Petróleo: $31,3 \%$; $2^{\circ}$ - Carvão, turfa e xisto: $28,6 \%$; $3^{\circ}$ - Gás natural: 21,2\%; $4^{\circ}$ - Biocombustíveis e resíduos (incluindo biomassa): 10,3\%; $5^{\circ}$ - Nuclear: 4,8\%; $6^{\circ}$ - Hidrelétrica: $2,4 \% ; 7^{\circ}$ - Fontes renováveis de energia (principalmente solar, geotérmica e eólica): 1,4\%. http://www.ren21.net/wp-content/uploads/2016/11/REN21_GSR2016_ KeyFindings port 02.pdf.

16 Reservas Provadas de Petróleo Bruto - 2017, bilhões de barris: 1) Venezuela; 2) Arábia Saudita; 3) Canadá; 4) Irã; 5) Iraque; 6) Kuwait; 7) Emirados Árabes Unidos; 8) Rússia; 9) Líbia; 10) Nigéria; 11) Estados Unidos; 12) Cazaquistão; 13) China; 14) Catar; 15) Brasil.https://www. eia.gov/beta/international/

17 Produção Total de Petróleo e Outros Líquidos - 2017. Mil Barris por Dia: 1) Estados Unidos; 2) Arábia Saudita; 3) Rússia; 4) Canadá; 5) China; 6) Irã; 7) Iraque; 8) Emirados Árabes Unidos; 9) Brasil; 10) Kuwait; 11) México; 12) Venezuela; 13) Nigéria; 14) Noruega; 15) Catar. Fonte: US Energy Information Administration, International energy statistics, https://www.eia.gov/beta/international/.

18 Exportações de Petróleo Bruto, incluindo Lease Condensate - 2016* (*ano mais recente com dados suficientes para classificação). Mil Barris por Dia: 1) Arábia Saudita; 2) Rússia; 3) Iraque; 4) Canadá; 5) Emirados Árabes Unidos; 6) Kuwait; 7) Irã; 8) Venezuela; 9) Angola; 10) Nigéria; 11) Noruega; 12) Cazaquistão; 13) México; 14) Omã; 15) Brasil.

19 Reservas recuperáveis de carvão - 2015* (*ano mais recente com dados suficientes para classificação) Milhões de Toneladas Curtas: 1) Estados Unidos; 2) Rússia; 3) Austrália; 4) China; 5) Índia; 6) Alemanha; 7) Ucrânia; 8) África do Sul; 9) Cazaquistão; 10) Indonésia; 11) Polônia; 12) Peru; 13) Nova Zelândia; 14) Sérvia; 15) Brasil.

20 As descobertas no pré-sal estão entre as mais importantes em todo o mundo na última década. Essa província é composta por grandes acumulações de óleo leve, de excelente qualidade e com alto valor comercial. http://www.petrobras.com.br/pt/nossas-atividades/areas-deatuacao/exploracao-e-producao-de-petroleo-e-gas/pre-sal/, acesso em: 02 de janeiro de 2019.

21 Conforme amplamente noticiado pela mídia, o leilão de campos do pré-sal realizado no final de outubro de 2017 teve seis dos oito blocos arrematados, gerando uma receita de 6,15 bilhões de reais em bônus de assinatura ao governo federal. Foi a primeira série de licitações do pré-sal sob a nova regra que desobriga a Petrobras de participar como sócia em todos os projetos.

22 A escalada dos preços internacionais do petróleo tem ajudado o caixa da União, dos estados e dos municípios. De janeiro a abril de 2018 , conforme amplamente divulgado pela mídia, a arrecadação com royalties e participações especiais sobre a produção do petróleo no país cresceu $38,5 \%$, na comparação com o mesmo período do ano passado, garantindo uma receita extra de $\mathrm{R} \$ 3,5$ bilhões. Segundo levantamento do Centro Brasileiro de Infraestrutura (CBIE), a partir de dados da Agência Nacional de Petróleo, Gás Natural e Biocombustíveis (ANP), essa fonte de receita atingiu $\mathrm{R} \$ 12,873$ bilhões nos 4 primeiros meses do ano, contra uma arrecadação de $\mathrm{R} \$ 9,292$ bilhões de janeiro a abril do ano passado.

23 Os principais usos das fontes não renováveis são: 1- na geração de eletricidade, 2- como combustível nos transportes de cargas e de pessoas e 3- no aquecimento de casas.

24 TOLMASQUIM, Mauricio T.; GUERREIRO, Amílcar; GORINI, Ricardo Matriz energética brasileira: uma prospectiva Novos estud. - CEBRAP n.79, São Paulo, Nov. 2007. 


\section{GRÁFICO 2}

\section{Evolução da estrutura da oferta de energia}

Brasil-1970-2030

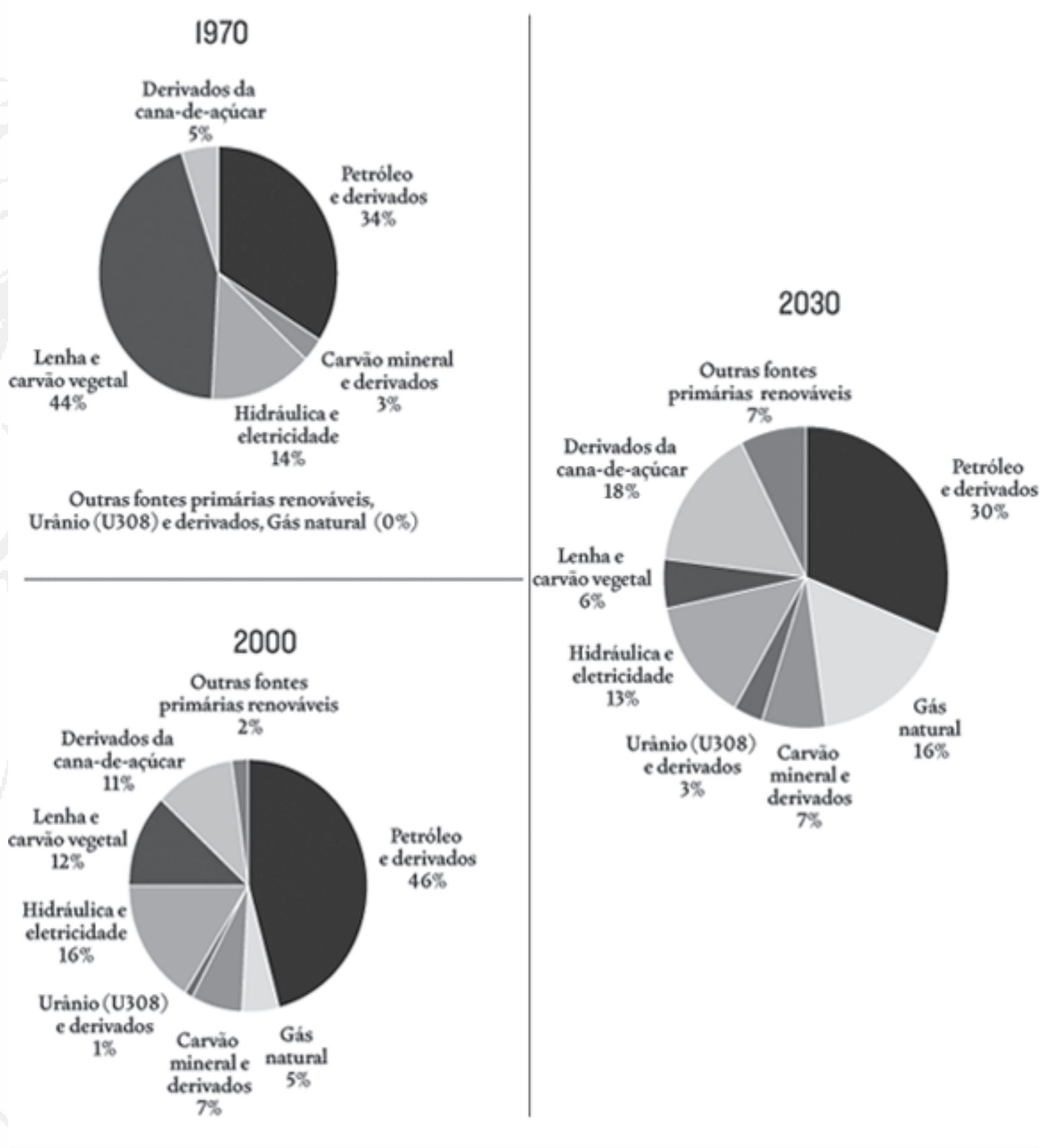

Fonte: EPE.

O petróleo, pois, para o Brasil (e para o mundo...), foi, é e continuará sendo por um bom tempo uma fonte de energia fundamental, além de excepcional fonte geradora de riquezas para o país, não podendo ser pura e simplesmente substituído na medida em que aludida substituição eliminaria sua função estratégica e não estaria adequadamente concatenada com as necessidades energéticas do País, o que efetivamente poderia fragilizar a confiabilidade e a segurança de 


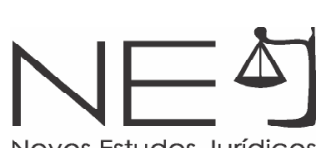

todo o nosso sistema energético nacional ${ }^{25}$. Possuindo, pois, importância econômica e histórica em nosso País, o petróleo sempre teve por parte do sistema constitucional e infraconstitucional brasileiro análise detalhada em face da importância de referido bem para a Nação.

Veja-se.

Ao tratar da tutela jurídica do petróleo, cabe lembrar, desde logo, que o denominado "ouro negro" só começa a receber tutela jurídica constitucional imediata a partir da Carta de 1967. Entretanto, no que se refere às legislações infraconstitucionais, nota-se menção ao termo petróleo já no século XIX, mais precisamente no Decreto Imperial n 3.352-A, de 30 de junho de 1864, no qual se concede ao inglês Thomas Sargent a "faculdade, pelo prazo de 90 anos, para lavrar por si ou por meio de uma companhia que organizar, dentro ou fora do Império, nas Comarcas de Camamu e Ilhéus, da província da Bahia... turfa, petróleo, ferro, cobre e quaisquer outros minerais que descobrir".

Oficialmente, é apenas em 1934, com a promulgação do Código de Minas (Decreto n²4.642, de 10-7-1934), que se verifica uma tutela mais abrangente e especificamente direcionada ao regramento do petróleo.

Assim sendo, para uma melhor compreensão da evolução do tema ao longo das Constituições brasileiras, necessária se faz uma breve incursão sobre a tutela jurídica do solo e do subsolo, tal qual apresentada pelas cartas de regência do Estado brasileiro.

É o que se fará de forma sucinta.

\subsubsection{O PETRÓleo NA CONSTITUIÇÃo DE 1824 E LEGISLAÇÃo INFRACONSTITUCIONAL ${ }^{26}$}

A tutela jurídica referida aos aspectos vinculados ao solo e ao subsolo na Constituição do Império era construída ao redor do tema da propriedade.

Conforme analisa Vaitsman²7, "a Independência e a Constituição de 25 de março de 1824 vieram abrir novas perspectivas aos empreendimentos no terreno mineral". Ensina o autor que prevaleceu a doutrina realenga da distinção entre solo e subsolo, fator primordial no desenvolvimento da

25 "A temática ambiental tem progressiva importância estratégica para o Brasil e traz novos desafios para o País na área de defesa. A proteção dos recursos naturais ganhou destaque na formulação da Estratégia Nacional de Defesa, principalmente no que se refere à região amazônica. O Brasil guia sua atuação na área ambiental pelo "Princípio 2 [18] da Declaração do Rio de Janeiro sobre Meio Ambiente e Desenvolvimento, adotada por ocasião da Conferência das Nações Unidas sobre Ambiente e Desenvolvimento Sustentável [19] (CNUMAD, ou Rio-92), o qual reafirma o direito soberano de cada nação de explorar seus recursos naturais segundo suas próprias políticas ambientais e de desenvolvimento. A contrapartida ao direito de exploração soberana é o compromisso de cada Estado de não causar danos ao meio ambiente em razão de atividades realizadas sob sua jurisdição ou sob seu controle." https://www.defesa.gov.br/arquivos/2012/mes07/lbdn.pdf, acesso em: 02 de janeiro de 2019.

26 Com relação aos autores/obras indicadas no item 1.1.1., vide FIORILLO, Celso Antonio Pacheco; FERREIRA, Renata Marques. Curso de direito da energia - Tutela jurídica da água, do petróleo, do biocombustível, dos combustíveis nucleares, do vento e do sol. 3. ed. São Paulo: Ed. Saraiva, 2015 
indústria de mineração. Assim, "as minas, antes propriedade da Coroa, estavam agora incorporadas ao domínio do Estado".

Por outro lado, Juarez Távora ${ }^{28}$ destacava que "durante a época colonial as minas existentes no Brasil pertenciam ao Rei de Portugal, e sua exploração por particulares se fazia mediante o contrato e o pagamento de uma regalia (o quinto da riqueza extraída)". Era o chamado regime regaliano, explicava o militar e político brasileiro. Toda a exploração era regulada pelos dispositivos das Ordenações Filipinas de 1603 então em vigor.

Na vigência do Império, as minas foram consideradas não pertencentes ao Imperador, ou à Coroa, mas, sim, propriedade nacional. Era o regime da propriedade dominial. Sua exploração deveria fazerse por concessões do poder público. Infelizmente, durante os quase 70 anos do Império, nenhuma lei substantiva codificou essa exploração, orientando-a, amparando-a ou mesmo estimulando-a, conforme indicam as lições do General.

Comentando o regime vigente sob a égide da Constituição do Império, Themistocles Brandão Cavalcanti $^{29}$ afirmava que, pelo sistema regaliano, também conhecido como sistema da dominialidade ou dominial, "a mina é propriedade do Estado, que pode, entretanto, conceder a sua exploração a terceiros, por um preço fixo ou participação nos lucros".

Explicava, à época, o importante constitucionalista, que o fundamento desse sistema estava no exercício da soberania, de que é titular o Estado, em nome de toda a coletividade. O conhecido autor ensina, ainda, que conforme observava Attilio Vivaqua, não se justificava a distinção entre a dominialidade e a regalia, sistemas que se confundiam em sua essência e em seu conteúdo de direito.

E continua Themistocles Brandão Cavalcanti ${ }^{30}$ :

Tem esse sistema uma razão que o justifica. Não tendo o proprietário do solo contribuído pelo seu esforço para o progresso e a produção da jazida, deve esta ser considerada uma riqueza comum, pertencente a todos e, portanto, do Estado, como expressão da coletividade. Contra esse sistema, insurgem-se aqueles que não admitem a socialização ou a intervenção do Estado. Alegam os inconvenientes do monopólio do Estado e o perigo das imposições fiscais 123. É o sistema em vigor do México, por força do parágrafo $4^{\circ}$ do Art. 27 da Constituição de 1937, que voltou assim à tradição colonial, depois de diversas reformas legislativas.

TÁVORA, Juarez. Petróleo para o Brasil. Rio de Janeiro: José Olympio, 1955.

CAVALCANTI, Themistocles Brandão. A Constituição Federal comentada. 2. ed. Rio de Janeiro: Konfino, 1952.

CAVALCANTI, Themistocles Brandão. A Constituição Federal comentada. 2. ed. Rio de Janeiro: Konfino, 1952. 
O ilustre autor ainda afirma, fundado nas lições de Gabino Junior, que:

La propiedad atribuída a la Nación sobre las substancias minerales, no es una propiedad privada regida por las normas de derecho civil, sino afectada a la satisfación de ciertos fines sociales como son la necesidad de satisfacer exigencias de carácter general, la de garantizar una eficaz explotación de los elementos naturales y de suprimir las cargas que los propietarios del suelo representan para un aprovechamiento regulado per el interés social.

Pontuava com propriedade Cavalcanti ${ }^{31}$ que aquele era o sistema da lei parmense de 1852 e da lei austríaca de 23 de maio de 1854, esta última tipicamente regaliana. Explicava ainda o autor que o sistema regaliano também era adotado "pelos países que, como a França e a Inglaterra, investiram pelo caminho da nacionalização, incorporando ao seu patrimônio as riquezas do seu subsolo ou pelo menos algumas dessas riquezas de aproveitamento mais imediato como, por exemplo, as minas de carvão".

É importante relembrar, ratificando tema já indicado anteriormente, que o direito de propriedade era considerado na época, pela Constituição de 1824, no preciso ensinamento de José Antonio Pimenta Bueno ${ }^{2}$, o Marquês de São Vicente, como "a faculdade ampla e exclusiva que cada homem tem de usar, gozar e dispor livremente do que licitamente adquiriu, do que é seu, sem outros limites que não sejam os da moral ou direitos alheios; é o jus utendi, et abutendi re sua; é também o direito de defendê-la e reivindicá-la".

Daí a visão da época de que o Estado tinha a faculdade ampla e exclusiva de usar, gozar e dispor livremente da mina que licitamente havia adquirido; dessa forma, na percepção jurídica do referido momento histórico (século XIX - Constituição de 1824), a mina era do Estado, tendo ele inclusive o direito de defendê-la e reivindicá-la de quem ilicitamente a possuísse.

Dessarte, conforme se pôde constatar, o fundamento constitucional da questão residia no art.179, XXII, que assim estabelecia:

É garantido o direito de propriedade em toda a sua plenitude. Se o bem público legalmente verificado exigir o uso e emprego da propriedade do cidadão, será elle, previamente indemnizado do valor della. A lei marcará os casos em que terá logar esta única excepção, e dará as regras para se determinar a indemnização.

A Constituição imperial estabeleceu o domínio nacional sobre os bens minerais e o direito do proprietário do solo no aproveitamento destes mesmos recursos minerais, independentemente de qualquer autorização por parte do Império, bastando, para tanto, o pagamento de um valor que era previamente estabelecido pela própria Coroa. Assim sendo, pelo texto de regência do Brasil de 1824,

31 CAVALCANTI, Themistocles Brandão. A Constituição Federal comentada. 2. ed. Rio de Janeiro: Konfino, 1952.

32 BUENO, José Antonio Pimenta. Direito Público Brasileiro e Análise da Constituição do Império Univ. Brasília, 1978. 
as minas e tudo que nelas eventualmente se encontrasse pertenciam ao Estado, sendo este uma expressão da coletividade.

\subsubsection{O PETRÓleO NA CONSTITUIÇÃO DE 1891 E A LEGISLAÇÃO INFRACONSTITUCIONAL}

A Constituição republicana de 1891, em seu art. 72, parágrafo 17, emendada em 7 de setembro de 1926, com relação ao tema ora estudado, estabelecia que:

O direito de propriedade mantém-se em toda a sua plenitude, salvo a desapropriação por necessidade, ou utilidade pública, mediante indemnização prévia.

a) As minas pertencem ao proprietário do solo, salvo as limitações estabelecidas por lei, a bem da exploração das mesmas.

b) As minas e jazidas mineraes necessárias à segurança e defesa nacionaes e as terras onde existirem não podem ser transferidas a estrangeiros.

Assim, de modo diferente da Constituição de 1824, o Texto de 1891 direcionava, categoricamente, a propriedade das jazidas minerais aos proprietários do solo. Dessa forma, embora mantida a visão doutrinária do conceito de propriedade, a Constituição de 1891, como ensinava Juarez Távora ${ }^{33}$, acabou por substituir o regime dominial de propriedade das minas, pelo regime de acessão, atribuindo a propriedade do subsolo e de suas riquezas ao proprietário do solo respectivo como propriedade acessória.

O chamado sistema fundiário ou de acessão, conforme ensinamentos de Themistocles Brandão Cavalcanti, ${ }^{34}$ seria aquele que atribuía a propriedade da mina ao proprietário do solo. Este era o sistema tradicional defendido pelos chamados fisiocratas.

O sistema de acessão, introduzido pela Constituição do Império, decorreria da noção absoluta do direito de propriedade e dessa forma abrangeria o solo, o subsolo e o espaço aéreo (cujos est solum, ejus est usque ad sidera et usque ad ínferos). Nesse regime, o Estado exerceria apenas a vigilância, a polícia, no sentido de orientar a exploração das riquezas minerais por parte dos proprietários das minas.

Ainda sobre o regime instaurado pelo Texto de 1891, o General Juarez Távora ${ }^{35}$ asseverava que tal fato, por colocar nas mãos dos proprietários do solo também as riquezas porventura existentes no subsolo como direito acessório, fez com que algumas empresas estrangeiras poderosas comprassem, no Estado de São Paulo, vastas áreas tidas como provavelmente petrolíferas, após

TÁVORA, Juarez. Petróleo para o Brasil. Rio de Janeiro: José Olympio, 1955.

CAVALCANTI, Themistocles Brandão. A Constituição Federal comentada. 2. ed. Rio de Janeiro: Konfino, 1952.

TÁVORA, Juarez. Petróleo para o Brasil. Rio de Janeiro: José Olympio, 1955. 


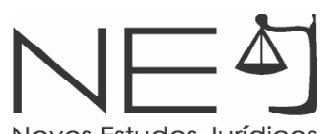

alguns estudos nas áreas realizados por geólogos americanos.

Durante a vigência do Texto de 1891, no plano infraconstitucional, vale destacar o Decreto n. 2.933 de 1915, em que se estabeleceu a nítida distinção entre a propriedade das minas e a propriedade do subsolo; a chamada Lei Calógeras (o engenheiro João Pandiá Calógeras foi quem efetivamente lutou pela aprovação do regramento que haveria por estabelecer a distinção entre a propriedade do solo e do subsolo, assegurando ao governo o direito de desapropriar o subsolo para explorá-lo), que seria regulamentada anos mais tarde pelo Decreto n. 15.211 de 1921, que estipulava que a mina era bem imóvel, acessória ao solo, mas dele distinta, separando-se assim legalmente o solo do subsolo.

Esse foi, em breve relato, o regime vigente no Brasil sob as luzes do Texto de 1891, em que se constatou que a propriedade da mina e do que nela se encontrasse era atribuída com exclusividade ao seu proprietário.

\subsubsection{O PETRÓleO NA CONSTITUIÇÃO DE 1934 E A LEGISLAÇÃO INFRACONSTITUCIONAL}

A Carta democrática de 1934 veio estabelecer aquilo que Juarez Távora ${ }^{36}$ chamou de "reação esboçada contra o estado de coisas encontrado pelo governo revolucionário de 1930".

Referida reação, para o importante político, teria se processado num tríplice sentido, a saber:

1) estabeleceram-se medidas de proteção voltadas para as riquezas naturais do país;

2) racionalizaram-se os respectivos processos de exploração; e, por fim,

3) centralizou-se a questão normativa da matéria em esfera federal.

Assim é que no campo constitucional foram fixados alguns princípios norteadores para as atividades referentes à exploração de nossos recursos naturais. Veja-se:

a) estabeleceu-se a competência privativa da União para legislar sobre: bens do domínio federal, riquezas do subsolo, mineração, metalurgia, águas, energia hidrelétrica, florestas, caça e pesca (art. 50, item IX, alínea j), não excluindo dessa competência a legislação estadual supletiva ou complementar sobre essas matérias, salvo se os bens fossem considerados de domínio federal (§ $3^{\circ}$ do art. 5으; ;

b) estabeleceu-se ainda a limitação ao direito de propriedade, de forma a coibir seu exercício contra os interesses sociais ou coletivos (art. 113, inciso 17) ${ }^{137}$; 
c) aboliu-se de forma implícita o direito de acessão, anteriormente conferido pela Constituição de 1891 ao proprietário do solo sobre o subsolo respectivo e suas riquezas, passando a propriedade a ser regulamentada por um regime sui generis de res nullius (art. 118);

d) institui-se um regime de autorizações e concessões para a exploração das riquezas do subsolo e para o aproveitamento da energia hidráulica - mesmo quando essa propriedade fosse considerada privada (art. 119);

e) estabeleceram-se restrições sobre a nacionalidade dos concessionários interessados em explorar essas riquezas ( $\S 1^{\circ}$ do art. 119) e ainda a nacionalização progressiva dessas riquezas (§ $4^{\circ}$ do art. 119);

f) por fim, estipulou-se o respeito aos direitos já adquiridos por proprietários de jazidas minerais (parte final do § 10 do art. 119) e por concessionários interessados em sua exploração ou no aproveitamento de energia hidráulica ( $\$$ 60 do art. 119) - tudo, porém, sem prejuízo de revisão desses direitos, a fim de adaptá-los às normas estabelecidas pela nova lei federal reguladora da matéria (art. 12 das Disposições Transitórias).

O regime ou o sistema de res nullius adotado pela Carta de 1934 efetivamente se opunha ao conhecido sistema da acessão, que era adotado pelo Texto de 1891.

Com relação ao regime estabelecido pelo Texto de 1934, Themistocles Brandão Cavalcanti ${ }^{37}$, à época, assim se pronunciava:

Pode-se mesmo dizer que dele derivam todos os demais porque, contestado o domínio do subsolo pelo proprietário do solo, admitido que as minas pertençam ao seu descobridor, estabelece-se, como consequência, a faculdade do Estado de conceder a sua exploração, independentemente de considerações de ordem puramente patrimonial.

O fato é que o sistema trazido pelo Texto de 1934 estava fundado em elementos eminentemente nacionalistas e estruturado por um forte discurso intervencionista.

A Constituição de 1934 acabou trazendo de volta a distinção antes existente entre a propriedade das jazidas e a propriedade do solo, passando a exploração de recursos minerais a depender da expedição de concessão federal aos interessados na pesquisa ou na lavra. O proprietário do solo continuou sendo o proprietário das jazidas conhecidas, mas o aproveitamento de novas jazidas minerais passou a depender da concessão federal, tendo o proprietário do solo, entretanto, a preferência em tais concessões.

37 CAVALCANTI, Themistocles Brandão. A Constituição Federal comentada. 2. ed. Rio de Janeiro: Konfino, 1952. 
O Texto Constitucional, combinado com os dispositivos trazidos pelo Código de Minas, buscava, dessa forma, afastar as empresas privadas da exploração do petróleo, ou pelo menos das áreas com eventuais possibilidades petrolíferas no Brasil; e assim o controle do importante hidrocarboneto estava definitivamente nas mãos do Estado.

Nesse sentido, o Código de Minas, em seu art. 30, determinava categoricamente que "as autorizações de pesquisa e concessões de lavra serão conferidas exclusivamente a brasileiros e a empresas organizadas no Brasil".

O Código de Minas foi uma legislação aprovada dias antes da promulgação do Texto Constitucional, fato este que acabou por indicar uma necessidade dos constituintes de 1934 em legitimar, pelo Texto Constitucional, os pontos referentes à estruturação do setor mineral que já haviam sido estabelecidos pelo Código, o que resultou em um movimento absolutamente contrário ao tradicional.

Houve nos trabalhos constituintes a atuação direta do então titular da pasta da Agricultura (Juarez Távora) perante a Assembleia Nacional Constituinte para a defesa dos pontos de vista consignados nos anteprojetos dos Códigos de Minas e de Águas.

A Constituição de 1934, entretanto, não duraria o suficiente para que a discussão se aprofundasse sobremaneira; logo, viria uma nova Carta Constitucional.

\subsubsection{O PETRÓleO NA CONSTITUIÇÃO DE 1937 E A LEGISLAÇÃO INFRACONSTITUCIONAL}

A Constituição Federal de 1937 acabou mantendo a preferência do proprietário do solo no aproveitamento dos recursos minerais e instituiu a exclusividade do regime de autorizações a brasileiros e empresas brasileiras. O Texto outorgado em 1937 causou amplas repercussões sobre a exploração das riquezas do solo por conta das alterações nele perpetradas. As principais modificações com relação ao Texto Constitucional anterior foram as seguintes:

a) Passou-se a exigir a nacionalidade brasileira para os acionistas das empresas de mineração (§ 10 do art. 143). A Constituição anterior apenas exigia que as sociedades de mineração fossem organizadas no Brasil (§ 1ㅇ do art. 119). Essa alteração acabou por praticamente afastar da atividade mineradora a colaboração antes proveniente do capital estrangeiro e, até mesmo, a do capital nacional pertencente a estrangeiros radicados e enriquecidos no Brasil.

b) Suprimiu-se o dispositivo constitucional anterior (art. 12 das Disposições Transitórias), que determinava a revisão dos contratos existentes, para o fim de adaptá-los às normas da nova legislação 
federal reguladora da matéria. Essa supressão permitiu às grandes empresas estrangeiras dedicadas à exploração da energia hidrelétrica, que haviam obtido contratos leoninos no regime anterior, fugir às exigências dispostas no art. 102 do Código de Águas, que lhes impedia de fazer novos fornecimentos de energia e realizar quaisquer ampliações sem se submeter previamente àquela revisão.

Assim, pelas disposições do Texto de 1937, a autonomia da mina em face da superfície foi ratificada, conforme se pôde observar.

Como se pode notar, o Texto de 1937 criou condições reais para a preservação do Código de Minas de 1934, com a ocorrência da efetivação do processo de nacionalização das jazidas pelo advento do Decreto-lei n. 366 de 1938, que em seu art. 96 assim estabelecia:

A lei não reconhece o domínio de particulares, como já instituído sobre as jazidas de petróleo e gases naturais, pelo fato de não ter sido descoberta nenhuma jazida desta classe suscetível de utilização industrial, enquanto vigorou o direito de acessão da propriedade do solo sobre as minas.

Assim é que o Estado ditatorial de Vargas, instaurado em 1937, acaba por editar o Decreto-lei n. 395 em 1938, que cria o Conselho Nacional do Petróleo, órgão responsável pela regulamentação do setor petrolífero no Brasil. O mesmo governo, considerando o abastecimento de petróleo questão de utilidade pública, nacionaliza de vez a indústria petrolífera no Brasil. O decreto mencionado permite, ainda, que o CNP inicie o processo de exploração de petróleo nacional, e é nessa época precisamente que começam de fato as explorações de petróleo em território brasileiro, sendo que no encaminhamento desses fatos a figura e a pressão exercidas por Monteiro Lobato se fizeram extremamente oportunas.

No ano de 1941, o Estado Novo acaba por rever sua postura nacionalista e reabre-se a possibilidade de grupos estrangeiros atuarem na exploração de petróleo. O Decreto-lei n. 3.553 de 1941 positiva essa oportunidade em seu art. 76 e, posteriormente, com o advento do Decreto-lei n. 6.230 no ano de 1944, amplia-se definitivamente a desnacionalização do setor mineral.

\subsubsection{O PETRÓlEO NA CONSTITUIÇÃO DE 1946 E A LEGISLAÇÃO INFRACONSTITUCIONAL}

O regime de exploração das riquezas do subsolo em nosso país, decorrente da Constituição de 1946, apontou, segundo os estudos de dizeres de Juarez Távora38, alguns dispositivos análogos aos da Constituição de 1934, bem como alguns dispositivos modificados ou suprimidos. Apesar de a nova Carta Magna estar fundamentada em um regime democrático, esclarecia o autor que existiam os seguintes dispositivos análogos aos da Constituição de 1934:

$38 \quad$ TÁVORA, Juarez. Petróleo para o Brasil. Rio de Janeiro: José Olympio, 1955. 
a) Abolição implícita do direito de acessão (art. 152), idêntico ao art. 118 da Constituição de 1934.

b) Regime de autorizações e concessões para pesquisa e lavra (art. 153), idêntico ao art. 119 da Constituição de 1934 (salva a supressão da cláusula final daquele artigo - "ainda que de propriedade privada").

c) Outros dispositivos não essenciais, da Constituição de 1934, foram mantidos pela Constituição de 1946.

Com relação ao dispositivo modificado, afirmava o autor mencionado que o § 1 @ do art. 153 da nova Constituição havia modificado o § 10 do art. 119 da Constituição de 1934, conferindo expressamente ao proprietário do solo a preferência na exploração das jazidas encontradas no subsolo respectivo. O dispositivo correspondente da Constituição anterior, na visão do autor, já concedia tal preferência não ao proprietário do solo, mas ao proprietário, por título idôneo, da jazida a ser explorada.

Embora o direito assegurado, pela Constituição de 1946, ao proprietário do solo se limitasse à preferência para a exploração das jazidas contidas no subsolo respectivo, não lhe garantia, entretanto, qualquer participação nos lucros dessa exploração, se esta fosse feita por um terceiro.

Juarez Távora ${ }^{39}$ afirmava, na época, que esse dispositivo poderia ser classificado como contrário à racionalização da indústria mineira. E afirmava ainda que "efetivamente: além de acarretar para essa indústria os tropeços decorrentes da inexperiência técnica e da incapacidade financeira da generalidade dos proprietários do solo - agravada, em muitos casos, pelas questões de condomínio (o que tudo importa em demorar e encarecer a produção) - abre uma porta ao monopólio das riquezas do subsolo, pela aquisição de extensas áreas de subsolo presumivelmente rico".

Segundo o autor da obra Petróleo para o Brasil40: "foi suprimido, na Constituição de 1946, o dispositivo da Constituição de 1934 que determinava a nacionalização progressiva das riquezas do subsolo e das fontes de energia hidráulica".

A supressão desse dispositivo constitucional, embora não impossibilitasse a lei ordinária de estabelecer preceitos conducentes àquela nacionalização, poderia suscitar controvérsias sobre as cláusulas contratuais de reversão sistemática ao patrimônio nacional dos acervos de empresas que explorassem energia hidráulica e algumas riquezas do subsolo, como o petróleo, afirmava à época, o autor.

39 TÁVORA, Juarez. Petróleo para o Brasil. Rio de Janeiro: José Olympio, 1955.

40 TÁVORA, Juarez. Petróleo para o Brasil. Rio de Janeiro: José Olympio, 1955. 
A autonomia da mina, em face da superfície, está reiterada nos dispositivos constitucionais de 1934, 1937 e 1946, não podendo deixar dúvidas; o que permite conciliar a propriedade individual da superfície, com a subordinação ao interesse social na exploração do subsolo, quer esta se verifique através da iniciativa estatal, quer através das concessões outorgadas pelo Estado aos particulares.

O regime da acessão é condenado. Pressupõe condições que se não ajustam às exigências do aproveitamento das riquezas minerais, sujeitando-o às possibilidades econômicas e financeiras do proprietário do solo, e das especulações que porventura tenham de fazer na exploração das riquezas, inteiramente estranhas às contingências da propriedade da superfície e de seu aproveitamento.

Caracterizou-se o novo sistema, quer dos Códigos de 1934 e 1940, quer das Constituições de 1934, 1937 e 1946 pelos seguintes princípios:

$\left.1^{\circ}\right)$ As minas e demais riquezas do subsolo constituem propriedade distinta da do solo para o efeito de exploração industrial;

$\left.2^{\circ}\right)$ O aproveitamento das minas e jazidas minerais, ainda que de propriedade privada, depende de autorização ou concessão do Governo Federal;

$\left.3^{\circ}\right)$ As autorizações ou concessões serão conferidas exclusivamente a brasileiros ou empresas organizadas no Brasil, ressalvada a preferência dos proprietários para exploração;

$\left.4^{\circ}\right)$ A competência para execução das disposições acima citadas passará para os Estados, desde que se achem tecnicamente aparelhados;

$5^{\circ}$ ) Finalmente, a competência para legislar sobre mineração é da União (art. $5^{\circ}, \mathrm{XV}$ ) da Constituição, cujas leis serão aplicadas para as explorações já existentes, e os seus contratos serão revestidos de conformidade com a legislação a ser elaborada pelo Congresso.

\section{E afirmava ainda o ilustre constitucionalista em síntese precisa:}

Este é, em resumo, o nosso regime minerário, quanto ao domínio sobre as minas e jazidas minerais, quanto ao que se refere ao regime de concessões e autorizações, e finalmente quanto à competência para legislar e conceder as pesquisas e explorações minerais ${ }^{42}$.

\section{A Constituição democrática de 1946, dessa forma, traduz o retorno da preferência do proprietário} do solo na exploração dos recursos minerais ocorrida no território brasileiro. 
Como se pôde notar, a grande novidade na tutela jurídica do petróleo estava justamente na possibilidade constitucional destinada a autorizar o legislador a elaborar de maneira aprofundada os direitos e os deveres adaptados à tutela jurídica do "ouro negro" no âmbito infraconstitucional. Foi o que ocorreu com a edição da Lei n. 2.004/53 que, por sua particular relevância e por fincar um marco definitivo na tutela jurídica do petróleo no Brasil, merece rápida e destacada análise.

\subsubsection{O PETRÓleO NA CONSTITUIÇÃO DE 1967 — EC N. 1/69 E A LEGISLAÇÃO INFRACONSTITUCIONAL}

Os Ministros da Marinha de Guerra, do Exército e da Aeronáutica Militar, usando das atribuições que Ihes conferia o art. 30 do Ato Institucional n. 16, de 14 de outubro de 1969, combinado com o § 10 do art. $2^{\circ}$ do Ato Institucional n. 5, de 13 de dezembro de 1968, outorgaram Emenda à Constituição promulgada em 24 de janeiro de 1967, reestruturando por completo o Estado brasileiro.

A dimensão apresentada pelo Texto de 1969 era tão extensa e as alterações tão substanciais, que parte da doutrina do direito constitucional afirma ser a EC n. 1 de 1969 verdadeira Constituição outorgada pelos titulares do poder revolucionário da época. De qualquer forma, o fato é que a Constituição de 24 de janeiro de 1967 passou a vigorar com redação adaptada aos interesses da ditadura militar, dentro de uma nova perspectiva voltada para a proteção e o resguardo das questões de "segurança nacional", em que evidentemente a tutela jurídica do petróleo mereceu atenção especial em face de sua clara importância estratégica para a Nação. Assim é que a pesquisa e a lavra de petróleo em território nacional passaram a merecer manifestação explícita da nova Carta em decorrência do que estabelecia o art. 169, a saber: "Art. 169. A pesquisa e a lavra de petróleo em território nacional constituem monopólio da União, nos termos da lei".

Conforme lembrava Pontes de Miranda ${ }^{43}$ a Constituição de 1967, artigo 169, estabeleceu cogentemente o monopólio do petróleo.

O monopólio instituído, portanto, na interpretação realizada em referido momento histórico, era o da União, que o exercia por meio do Conselho Nacional do Petróleo (como já antes referido, órgão de orientação e fiscalização) e da Petrobras (como órgão de execução). A Petrobras, dessa forma, detinha o privilégio legal de exercer uma atividade monopolizada pela União, consistente na pesquisa, lavra, refinação, distribuição, importação, exportação, comércio e transporte de petróleo, de seus derivados e de gases naturais. Achavam-se excluídos do monopólio estatal, que incidia sobre o setor petrolífero, apenas:

43 PONTES DE MIRANDA, Francisco Cavalcanti. Comentários à Constituição de 1967 com a emenda no 1 de 1969. 3. ed. Rio de Janeiro: Forense, 1987. 
a) a venda a varejo; e

b) o transporte de produtos petrolíferos industrializados.

As jazidas petrolíferas, na época, integravam o domínio público federal, conforme já antes afirmado, e pertenciam à União. O proprietário do imóvel onde fosse localizado petróleo não tinha direito a qualquer participação nos resultados da lavra.

Só os Estados-Membros e os Territórios Federais, em cujas áreas se fizesse a lavra do petróleo, teriam direito a uma participação compensatória correspondente a um determinado índice percentual sobre o valor do petróleo extraído. A Petrobras, em consequência do privilégio legal que possuía, tinha o direito de perseguir e lavrar o petróleo em propriedades particulares e sobre elas constituir servidões, pagando indenização pelos danos causados ao proprietário em relação à superfície do solo. Atuava, dessa forma, como uma empresa concessionária do Governo Federal, direcionada para a execução das atividades petrolíferas monopolizadas.

Como já antes referido, e sob a égide da ditadura militar, o sistema do monopólio estatal (monopólio da União) foi indicado claramente no que se refere à pesquisa e à lavra de petróleo em todo o território nacional. Todavia, com a ruptura e o derradeiro fim do regime militar em nosso país, uma nova ordem democrática superou os temas regrados pela Carta de 1967, emendada em 1969, passando a estabelecer não só pioneira natureza jurídica no que se refere ao petróleo, como ainda disciplinando novos critérios destinados à sua efetiva inserção econômica em uma ordem jurídica capitalista. É o que se passará a desenvolver a seguir.

Verificou-se, portanto, que não basta a edição de um simples Decreto Legislativo para afastar de forma ampla geral e irrestrita todo um arcabouço de regras jurídicas vinculadas à tutela jurídica do petróleo desenvolvida historicamente até o advento de nossa Carta Magna atual.

1.1.7. O petróleo no ÂMbito do Estado Democrático de Direito (CONSTITUiçÃo de 1988): A SOBERANIA E A INDEPENDÊNCIA NACIONAL ASSEGURANDO UMA POLÍTICA ENERGÉTICA SUSTENTÁVEL

Atenta, pois à evolução normativa histórica do petróleo em proveito dos brasileiros, nossa Constituição Federal de 1988 estruturou de forma satisfatória a tutela jurídica do referido bem ambiental, delimitando suas especificidades de gestão na ordem econômica constitucional na forma do Art.177, sem se olvidar evidentemente que a gestão do referido hidrocarboneto necessariamente deve ser interpretada preliminarmente em face dos princípios fundamentais de nossa Lei Maior (Arts. $1^{\circ}, 3^{\circ}$ e $4^{\circ}$ da CF), bem como dos princípios gerais da atividade econômica (Art.170 e segs,) 
assim como obedecendo evidentemente ao regramento jurídico geral definidor da natureza jurídica da mencionada fonte de energia (petróleo como bem ambiental - Art.225 da CF) ${ }^{44}$.

\section{Com efeito.}

No que se refere à gestão do petróleo em face dos princípios fundamentais de nossa Lei Maior, merece ser destacado, ainda que superficialmente, que toda e qualquer política energética nacional, no plano normativo, deve obedecer preliminarmente aos princípios fundamentais da soberania (Art. $1^{\circ}$, I da CF) e da independência nacional (Art.4 $\left.4^{\circ}, \mathrm{I}\right)$ como fundamentos estruturais destinados a interpretar a matéria. Destarte, "o art. $1^{\circ}$ da Constituição assenta como um dos fundamentos do Estado brasileiro a sua soberania - que significa o poder político supremo dentro do território, e, no plano internacional, no tocante às relações da República Federativa do Brasil com outros Estados soberanos, nos termos do art. $4^{\circ}, \mathrm{l}$, da Carta Magna. A soberania nacional no plano transnacional funda-se no princípio da independência nacional, efetivada pelo presidente da República, consoante suas atribuições previstas no art. 84, VII e VIII, da Lei Maior"45, ou seja, trata-se de entender a soberania como "poder de mando de última instância, numa sociedade política" para usar a tradicional lição de Matteucci46. Daí o Supremo Tribunal Federal ter estabelecido que "os compromissos assumidos pelo Brasil em tratado internacional de que seja parte $\left(\S 2^{\circ}\right.$ do art. $5^{\circ}$ da Constituição) não minimizam o conceito de soberania do Estado-povo na elaboração da sua Constituição"47, mantendo-se, pois,

$44 \quad$ Para um estudo detalhado, vide FIORILLO, Celso Antonio Pacheco; FERREIRA, Renata Marques. Curso de direito da energia - Tutela jurídica da água, do petróleo, do biocombustível, dos combustíveis nucleares, do vento e do sol. 3. ed. São Paulo: Ed. Saraiva, 2015.

45 "Negativa, pelo presidente da República, de entrega do extraditando ao país requerente. (...) O Tratado de Extradição entre a República Federativa do Brasil e a República Italiana, no seu art. III, 1, f, permite a não entrega do cidadão da parte requerente quando "a parte requerida tiver razões ponderáveis para supor que a pessoa reclamada será submetida a atos de perseguição". (...) Deveras, antes de deliberar sobre a existência de poderes discricionários do presidente da República em matéria de extradição, ou mesmo se essa autoridade se manteve nos lindes da decisão proferida pelo Colegiado anteriormente, é necessário definir se o ato do chefe de Estado é sindicável pelo Judiciário, em abstrato. $\mathrm{O}$ art. $1^{\circ}$ da Constituição assenta como um dos fundamentos do Estado brasileiro a sua soberania - que significa o poder político supremo dentro do território, e, no plano internacional, no tocante às relações da República Federativa do Brasil com outros Estados soberanos, nos termos do art. $4^{\circ}$, I, da Carta Magna. A soberania nacional no plano transnacional funda-se no princípio da independência nacional, efetivada pelo presidente da República, consoante suas atribuições previstas no art. 84, VII e VIII, da Lei Maior. A soberania, dicotomizada em interna e externa, tem na primeira a exteriorização da vontade popular (art. 14 da CRFB) através dos representantes do povo no parlamento e no governo; na segunda, a sua expressão no plano internacional, por meio do presidente da República. No campo da soberania, relativamente à extradição, é assente que o ato de entrega do extraditando é exclusivo, da competência indeclinável do presidente da República, conforme consagrado na Constituição, nas leis, nos tratados e na própria decisão do Egrégio STF na Ext. 1.085. O descumprimento do Tratado, em tese, gera uma lide entre Estados soberanos, cuja resolução não compete ao STF, que não exerce soberania internacional, máxime para impor a vontade da República Italiana ao chefe de Estado brasileiro, cogitando-se de mediação da Corte Internacional de Haia, nos termos do art. 92 da Carta das Nações Unidas de 1945." [Rcl 11.243, rel. p/ o ac. min. Luiz Fux, j. 8-6-2011, P, DJE de 5-10-2011].

46 MATEUCCI, Nicola Dicionário de política I Norberto Bobbio, Nicola Matteucci e Gianfranco Pasquino; trad. Carmen C, Varriale et al.; coord. trad. João Ferreira; rev. geral João Ferreira e Luis Guerreiro Pinto Cacais. - Brasília: Editora Universidade de Brasília, 1 la ed., 1998.

47 "EMENTA: "HABEAS-CORPUS" PREVENTIVO. PRISÃO CIVIL DE DEPOSITÁRIO INFIEL DECRETADA EM AÇÃO DE DEPÓSITO DE BEM ALIENADO FIDUCIARIAMENTE (ART. 66 DA LEI No 4.728/65 E DECRETO-LEI No 911/69): ART. 5, LXVII, DA CONSTITUIÇÃO E CONVENÇÃO AMERICANA SOBRE DIREITOS HUMANOS (PACTO DE SÃO JOSÉ DA COSTA RICA), DECR. Nº 678/92. ALEGAÇÃO DE PRESCRIÇÃO DA PRETENSÃO PUNITIVA. I - Preliminar. Questão nova: prescrição. O Tribunal "a quo" não pode ser considerado coator quanto às questões que não Ihe foram submetidas e, neste caso, a autoridade coatora continua sendo o Juiz de primeiro grau: incompetência do Supremo Tribunal Federal. "Habeas-corpus" não conhecido nesta parte. Precedentes. II - Mérito. 1- A Constituição proíbe a prisão civil por dívida, mas não a do depositário que se furta à entrega de bem sobre o qual tem a posse imediata, seja o depósito voluntário ou legal (art. $5^{\circ}$, LXVII). 2- Os arts. $1^{\circ}$ (art. 66 da Lei $n^{\circ} 4.728 / 65$ ) e $4^{\circ}$ do Decreto-lei $n^{\circ} 911 / 69$ definem o devedor alienante fiduciário como depositário, porque o domínio e a posse direta do bem continuam em poder do proprietário fiduciário ou credor em face da natureza do contrato. 3- A prisão de quem foi declarado, por decisão judicial, como depositário infiel é constitucional, seja quanto ao depósito regulamentado no Código Civil como no caso de alienação protegida pela cláusula fiduciária. 4- Os compromissos assumidos pelo Brasil em tratado internacional de que seja parte ( $2^{\circ}$ do art. $5^{\circ}$ da Constituição) não minimizam o conceito de soberania do Estado-povo na elaboração da sua Constituição; por esta razão, o art. $7^{\circ}, n^{\circ} 7$, do Pacto de São José da Costa Rica ("ninguém deve ser detido por dívida": "este princípio não limita os mandados de autoridade judiciária competente expedidos em virtude de inadimplemento de obrigação alimentar") deve ser interpretado com as limitações impostas pelo art. $5^{\circ}$, LXVII, da Constituição. 5- "Habeas-corpus" conhecido em parte e, nesta parte, indeferido." HC 73044 / SP - SÃO PAULO HABEAS CORPUS. Relator(a): Min. MAURÍCIO CORRÊA Julgamento: 19/03/1996Ｏ́rgão Julgador: Segunda Turma Publicação DJ 20-09-1996 PP-34534 EMENT. VOL-01842-02 PP-001. 
nos dias de hoje, "ainda intacto o padrão westfaliano de relacionamento horizontal entre os Estados, como modelo fundado na soberania, na supremacia da ordem jurídica interna, na aplicação do direito internacional em conformidade com os ditames da legislação local e na consideração de um povo territorialmente localizado como fonte de legitimidade, ainda que, em outras áreas, sobretudo na econômica, a heteronímia decisória tenda a avançar cada vez mais", como lembra Lewandowski ${ }^{48}$.

Por outro lado, tendo natureza jurídica de bem ambiental, o petróleo obedece ao regramento constitucional do direito ambiental em face de seus princípios fundamentais (Art., 225 da CF), conforme já se teve oportunidade de destacar anteriormente ${ }^{49}$. Assim, os comandos constitucionais antes aduzidos estabelecerem uma orientação inequívoca no que se refere à estruturação superior da política energética nacional brasileira, com destaque para a tutela jurídica do petróleo e do carvão, visando concretamente garantir o desenvolvimento nacional (Art. $3^{\circ}$, II da CF) com o objetivo de erradicar a pobreza e a marginalização e reduzir as desigualdades sociais e regionais (Art. $3^{\circ}$, III), visando, numa economia capitalista (Art. $1^{\circ}, \mathrm{IV}$ e 170 e segs. da CF) balizada pela sustentabilidade (Art.170,VI c/c Art.225), construir uma sociedade livre, justa e solidária (Art.3 ${ }^{\circ}$ I) em proveito da dignidade da pessoa humana (Art. $1^{\circ}, \mathrm{III}$ da CF).

Passa-se, pois, a observar os fundamentos infraconstitucionais da política energética nacional.

\section{FUNDAMENTOS INFRACONSTITUCIONAIS DA POLÍTICA ENERGÉTICA NACIONAL BRASILEIRA: A TUTELA JURÍDICA DO PETRÓLEO E DO CARVÃO EM FACE DA LEI 9.478/97}

A Lei 9478/07, ao dispor sobre a denominada política energética nacional, assim como as atividades relativas ao monopólio do petróleo, indicou de forma explícita (Art. $1^{\circ}$ ) uma série de objetivos destinados a dar efetividade aos comandos constitucionais anteriormente indicados.

Com efeito.

Embora não se olvide da proteção ao meio ambiente (Art.1ํ, IV), destaca a Lei 9478/07 a necessidade de garantir o fornecimento de derivados de petróleo em todo o território nacional, nos termos do $\S 2^{\circ}$ do art. 177 da Constituição Federal (Art.1ํ, V), ampliando a competitividade do País no mercado internacional $\left(\operatorname{Art} .1^{\circ}, \mathrm{XI}\right)$, promovendo o desenvolvimento, ampliando o mercado de trabalho e valorizando os recursos energéticos (Art. $\left.1^{\circ}, \mathrm{II}\right)$, visando preservar o interesse nacional $\left(\right.$ Art. $\left.1^{\circ}, \mathrm{I}\right)$.

48 LEWANDOWSKI, Enrique Ricardo. Globalização, Regionalização e Soberania. São Paulo: Editora Juarez de Oliveira, 2004.

49 Para um estudo detalhado, vide FIORILLO, Celso Antonio Pacheco. Curso de Direito Ambiental Brasileiro. 19. ed. revista, ampliada e atualizada São Paulo: Saraiva, 2019; FIORILLO, Celso Antonio Pacheco; FERREIRA, Renata Marques. Curso de direito da energia - Tutela jurídica da água, do petróleo, do biocombustível, dos combustíveis nucleares, do vento e do sol. 3. ed. São Paulo: Ed. Saraiva, 2015. 
Assim, observando detalhada organização normativa destinada a gerenciar a gestão do petróleo em nosso País, inclusive criando uma agência nacional destinada a regular a indústria do petróleo, indica a Lei 9478/97 normas gerais vinculadas ao balizamento normativo tanto da exploração como da produção e refino do petróleo, não se olvidando de estabelecer regras destinadas a orientar a atividade de importação e exportação de petróleo.

Cuida a norma jurídica antes referida, por via de consequência, de tutelar adequadamente as reservas, a produção, assim como a exportação de petróleo brasileiro considerando evidentemente, como já aduzido anteriormente, as especificidades de um País - o Brasil - que se destaca nas reservas das duas fontes de energia mais utilizadas do mundo (fontes que correspondem a aproximadamente $60 \%$ do total).

Claro está por via de consequência que em nenhum momento o sistema normativo nacional pretendeu abdicar - no âmbito constitucional e no âmbito infraconstitucional - da prerrogativa de usar fonte de energia não renovável existente em abundância em nosso País (o petróleo), sem prejuízo das determinações constitucionais aplicáveis à tutela constitucional dos bens ambientais, em face da existência de um simples Decreto Legislativo (o Decreto Legislativo 140 de 2016).

Daí prevalecer evidentemente os comandos constitucionais e infraconstitucionais relativos à gestão da referida fonte de energia não renovável particularmente em face da fundamental necessidade de enfatizar "a relação intrínseca entre as ações, as respostas e os impactos da mudança do clima e o acesso equitativo ao desenvolvimento sustentável e à erradicação da pobreza" previstos no Acordo de Paris.

\section{A POLÍTICA ENERGÉTICA NACIONAL BRASILEIRA E O ACORDO DE PARIS: O DESENVOLVIMENTO SUSTENTÁVEL E OS RESULTADOS ECONÔMICOS DA GESTÃO DO PETRÓlEO EM PROVEITO DA ERRADICAÇÃO DA POBREZA NO BRASIL}

No que se refere à necessidade de enfatizar a relação intrínseca entre as ações, as respostas e os impactos da mudança do clima e o acesso equitativo ao desenvolvimento sustentável e à erradicação da pobreza (Arts. $1^{\circ}$ e $3^{\circ}$ da Constituição Federal), nosso sistema normativo adotou equilibrado critério destinado a assegurar o uso de energia não renovável de forma sustentável, ou seja, nossa política energética nacional guarda rigorosa harmonia com o princípio do desenvolvimento sustentável.

Com efeito. 
Conforme já tivemos oportunidade de aduzir em nossas obras ${ }^{50}$, a terminologia empregada a este princípio surgiu, inicialmente, na Conferência Mundial de Meio Ambiente, realizada, em 1972, em Estocolmo e repetida nas demais conferências sobre o meio ambiente, em especial na ECO-92, a qual empregou o termo em onze de seus vinte e sete princípios.

A Conferência das Nações Unidas sobre o Desenvolvimento Sustentável realizada no Rio de Janeiro/BRASIL em junho de 2012 - a Rio+2051 -, ao publicar seu documento final intitulado $O$ FUTURO QUE QUEREMOS (59 páginas com 283 parágrafos/itens organizados em 6 capítulos, a saber (tradução livre do texto original em espanhol): Nossa Visão Comum, Renovação dos Compromissos Políticos, Economia Verde, Marco Institucional para o Desenvolvimento Sustentável, Marco para Ação e Implementação e Meios de Execução), reafirmou todos os princípios da Declaração do Rio sobre o Meio Ambiente e Desenvolvimento.

Na Constituição Federal de 1988, o princípio do desenvolvimento sustentável encontra-se esculpido no caput do art. 225:

Art. 225. Todos têm direito ao meio ambiente ecologicamente equilibrado..., impondo-se ao Poder Público e à coletividade o dever de defendê-lo e preservá-lo para as presentes e futuras gerações (grifo nosso).

Constata-se que os recursos ambientais (evidentemente o petróleo também) não são inesgotáveis, tornando-se inadmissível que as atividades econômicas se desenvolvam alheias a esse fato. Busca-se com isso a coexistência harmônica entre economia e meio ambiente. Permite-se o desenvolvimento, mas de forma sustentável, planejada, para que os recursos hoje existentes não se esgotem ou tornem-se inócuos. Dessa forma, o princípio do desenvolvimento sustentável tem por conteúdo a manutenção das bases vitais da produção e da reprodução do homem e das suas atividades, garantindo igualmente uma relação satisfatória entre os homens e destes com o seu ambiente, para que as futuras gerações também tenham oportunidade de desfrutar os mesmos recursos que existem hoje à nossa disposição.

A compreensão do instituto reclama a sua contextualização histórica. Isso porque se sabe que o liberalismo se tornou um sistema inoperante diante do fenômeno da revolução das massas. Em face da transformação sociopolítico-econômico-tecnológica, percebeu-se a necessidade de um modelo estatal intervencionista, com a finalidade de reequilibrar o mercado econômico.

50 FIORILLO, Celso Antonio Pacheco. Curso de Direito Ambiental Brasileiro. 19. ed. revista, ampliada e atualizada São Paulo: Saraiva, 2019.

51 Conferência das Nações Unidas sobre o Desenvolvimento Sustentável, a Rio+20 foi realizada de 13 a 22-6-2012 na cidade do Rio de Janeiro. A Rio+20 foi assim conhecida porque marcou os vinte anos de realização da Conferência das Nações Unidas sobre Meio Ambiente e Desenvolvimento (Rio-92) e contribuiu para definir a agenda do desenvolvimento sustentável para as próximas décadas. A proposta brasileira de sediar a Rio+20 foi aprovada pela Assembleia Geral das Nações Unidas, em sua 64a Sessão, em 2009. O objetivo da Conferência foi a renovação do compromisso político com o desenvolvimento sustentável, por meio da avaliação do progresso e das lacunas na implementação das decisões adotadas pelas principais cúpulas sobre o assunto e do tratamento de temas novos e emergentes. A Conferência teve dois temas principais: • A economia verde no contexto do desenvolvimento sustentável e da erradicação da pobreza; e $\bullet$ A estrutura institucional para o desenvolvimento sustentável. Disponível em: <http:// www.rio20.gov.br>. 


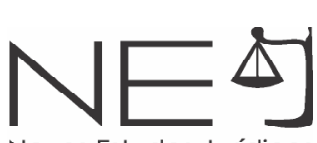

Com isso, a noção e o conceito de desenvolvimento, formados num Estado de concepção liberal, alteraram-se, porquanto não mais encontravam guarida na sociedade moderna. Passou-se a reclamar um papel ativo do Estado no socorro dos valores ambientais, conferindo outra noção ao conceito de desenvolvimento. A proteção do meio ambiente e o fenômeno desenvolvimentista (sendo composto pela livre iniciativa) passaram a fazer parte de um objetivo comum, pressupondo "a convergência de objetivos das políticas de desenvolvimento econômico, social, cultural e de proteção ambiental"52.

A busca e a conquista de um 'ponto de equilíbrio' entre o desenvolvimento social, o crescimento econômico e a utilização dos recursos naturais exigem um adequado planejamento territorial que tenha em conta os limites da sustentabilidade. O critério do desenvolvimento sustentável deve valer tanto para o território nacional na sua totalidade, áreas urbanas e rurais, como para a sociedade, para o povo, respeitadas as necessidades culturais e criativas do país"53.

Como se percebe, o princípio possui grande importância, porquanto numa sociedade desregrada, à deriva de parâmetros de livre concorrência e iniciativa, o caminho inexorável para o caos ambiental é uma certeza. Não há dúvida de que o desenvolvimento econômico também é um valor precioso da sociedade. Todavia, a preservação ambiental e o desenvolvimento econômico devem coexistir, de modo que aquela não acarrete a anulação deste. Atento a esses fatos, o legislador constituinte de 1988 verificou que o crescimento das atividades econômicas merecia um novo tratamento. Não mais poderíamos permitir que elas se desenvolvessem alheias aos fatos contemporâneos. A preservação do meio ambiente passou a ser palavra de ordem, porquanto sua contínua degradação implicará diminuição da capacidade econômica do País, e não será possível à nossa geração e principalmente às futuras desfrutar uma vida com qualidade.

Assim, a livre iniciativa, que rege as atividades econômicas, começou a ter outro significado. A liberdade de agir e dispor tratada pelo Texto Constitucional (a livre iniciativa) passou a ser compreendida de forma mais restrita, o que significa dizer que não existe a liberdade, a livre iniciativa, voltada à disposição de um meio ambiente ecologicamente equilibrado. Este deve ser o objetivo. Busca-se, na verdade, a coexistência de ambos sem que a ordem econômica inviabilize um meio ambiente ecologicamente equilibrado e sem que este obste o desenvolvimento econômico.

Tanto isso é verdade que a Constituição Federal estabelece que a ordem econômica, fundada

$52 \quad$ O Tribunal Regional Federal da 3a Região (São Paulo/Mato Grosso do Sul) adotou nosso entendimento, conforme se observa de importante decisão da Presidente do TRF, Desembargadora Federal Marli Marques Ferreira, ao enfrentar o tormentoso tema da queima da palha da cana-de-açúcar, a saber: "Celso Antonio Pacheco Fiorillo, com a proficiência de profundo conhecedor da matéria e cuidando do Princípio do Desenvolvimento Sustentável, leciona: "Com isso, a noção e o conceito de desenvolvimento, formados num Estado de concepção liberal, alteraram-se, porquanto não mais encontravam guarida na sociedade moderna. Passou-se a reclamar um papel ativo do Estado no socorro dos valores ambientais, conferindo outra noção ao conceito de desenvolvimento. A proteção do meio ambiente e o fenômeno desenvolvimentista (sendo composto pela livre iniciativa) passaram a fazer parte de um objetivo comum, pressupondo 'a convergência de objetivos das políticas de desenvolvimento econômico, social, cultural e de proteção ambiental'” (TRF, 3a Região, Proc. n. 2007.03.00.091882-6, requerente: Estado de São Paulo, requerido: Juízo Federal da $1^{\text {a }}$ Vara de Jaú - Seç. Jud. - SP, setembro de 2007). 
na livre iniciativa (sistema de produção capitalista) e na valorização do trabalho humano (limite ao capitalismo selvagem), deverá regrar-se pelos ditames de justiça social, respeitando o princípio da defesa do meio ambiente, contido no inciso VI do art. 170. Assim, caminham lado a lado a livre concorrência e a defesa do meio ambiente, a fim de que a ordem econômica esteja voltada à justiça social. Veja-se o dispositivo:

Art. 170. A ordem econômica, fundada na valorização do trabalho humano e na livre iniciativa, tem por fim assegurar a todos existência digna, conforme os ditames da justiça social, observados os seguintes princípios:

(...)

$\mathrm{VI}$ - defesa do meio ambiente, inclusive mediante tratamento diferenciado conforme o impacto ambiental dos produtos e serviços e de seus processos de elaboração e prestação.

Deve-se lembrar que a ideia principal é assegurar a existência digna da pessoa humana por meio de uma vida com qualidade ${ }^{54,55}$.

Com isso, o princípio não objetiva impedir o desenvolvimento econômico. Sabe-se que a atividade econômica, na maioria das vezes, representa alguma degradação ambiental. Todavia, o que se procura é minimizá-la, pois pensar de forma contrária significaria dizer que nenhum empreendimento que venha a afetar o meio ambiente poderá ser instalado, e não é essa a concepção apreendida do texto. O correto é que as atividades sejam desenvolvidas, lançando-se mão dos instrumentos existentes adequados para a menor degradação possível. Daí a fundamental importância do evento mundial realizado no Brasil em 2012, relacionando a necessidade de erradicação da pobreza com o meio ambiente em todo o planeta.

Por isso, delimita-se o princípio do desenvolvimento sustentável como o desenvolvimento que atenda às necessidades do presente, sem comprometer as futuras gerações dentro dos parâmetros anteriormente indicados.

54 "O princípio do desenvolvimento sustentável, além de impregnado de caráter eminentemente constitucional, encontra suporte legitimador em compromissos internacionais assumidos pelo Estado brasileiro e representa fator de obtenção do justo equilíbrio entre as exigências da economia e as da ecologia, subordinada, no entanto, a invocação desse postulado, quando ocorrente situação de conflito entre valores constitucionais relevantes, a uma condição inafastável, cuja observância não comprometa nem esvazie o conteúdo essencial de um dos mais significativos direitos fundamentais: o direito à preservação do meio ambiente, que traduz bem de uso comum da generalidade das pessoas, a ser resguardado em favor das presentes e futuras gerações" (ADI 3.540-MC, Rel. Min. Celso de Mello, j. em 1-9-2005, Plenário, DJ de 3-22006).

55 "É certo que a ordem econômica na Constituição de 1988 define opção por um sistema no qual joga um papel primordial a livre-iniciativa. Essa circunstância não legitima, no entanto, a assertiva de que o Estado só intervirá na economia em situações excepcionais. Mais do que simples instrumento de governo, a nossa Constituição enuncia diretrizes, programas e fins a serem realizados pelo Estado e pela sociedade. Postula um plano de ação global normativo para o Estado e para a sociedade, informado pelos preceitos veiculados pelos seus arts. $1^{\circ}, 3^{\circ}$ e 170 . A livre-iniciativa é expressão de liberdade titulada não apenas pela empresa, mas também pelo trabalho. Por isso a Constituição, ao contemplála, cogita também da 'iniciativa do Estado'; não a privilegia, portanto, como bem pertinente apenas à empresa. Se de um lado a Constituição assegura a livre-iniciativa, de outro determina ao Estado a adoção de todas as providências tendentes a garantir o efetivo exercício do direito à educação, à cultura e ao desporto (arts. 23, V, 205, 208, 215 e 217, § $3^{\circ}$, da Constituição). Na composição entre esses princípios e regras há de ser preservado o interesse da coletividade, interesse público primário. O direito ao acesso à cultura, ao esporte e ao lazer são meios de complementar a formação dos estudantes" (ADI 1.950, Rel. Min. Eros Grau, j. em 3-11-2005, Plenário, DJ de 2-6-2006). No mesmo sentido: ADI 3.512, j. em 15-2-2006, Plenário, DJ de 23-6-2006. 
Destarte, observando-se necessariamente o objetivo do desenvolvimento sustentável previsto inclusive no Acordo de Paris como diretriz interpretativa do uso da energia, nosso ordenamento normativo visa estabelecer a adequada interpretação da matéria vinculada à erradicação da pobreza e da marginalização, assim como reduzir as desigualdades sociais e regionais existentes em nosso país com o uso racional e equilibrado dos bens ambientais (inclusive e particularmente do petróleo) como uma das importantes formas disponíveis para garantir o desenvolvimento nacional (art. $3^{\circ}$, II) em proveito da dignidade dos brasileiros (art. 1ㅇ, III, da CF).

Daí a necessidade de relembrar a visão adotada pelos 193 países que participaram em junho de 2012 da Conferência das Nações Unidas sobre o Desenvolvimento Sustentável, realizada no Brasil (a Rio + 20), indicando em documento formal que a erradicação da pobreza é o maior desafio global que o mundo enfrenta atualmente e é um requisito indispensável para o desenvolvimento sustentável.

creando oportunidades de empleo y trabajo decente para todos, manteniendo al mismo tiempo el funcionamiento saludable de los ecosistemas de la Tierra".

\section{CONCLUSÃO}

A política energética nacional brasileira, interpretada em face dos Princípios Fundamentais, bem como dos princípios Gerais da Atividade Econômica de nossa Lei Maior (particularmente o da defesa do meio ambiente), assim como no plano infraconstitucional, ao regramento normativo fixado pela Política Nacional sobre Mudança do Clima (Lei 12187/09) e ao conteúdo normativo estruturado pela Política Energética Nacional (Lei 9.478/97), visa garantir de forma soberana a segurança energética necessária para o desenvolvimento do Brasil em proveito da dignidade dos brasileiros e dos estrangeiros residentes no País. Destarte, o denominado Acordo de Paris, aprovado em nosso País por um simples Decreto Legislativo (o Decreto Legislativo140/16), tem sua efetividade jurídica concretamente condicionada ao que estabelecem os fundamentos normativos constitucionais antes estabelecidos, não tendo o condão de afetar a Soberania Energética Constitucional estabelecida em nosso País como relevante instrumento destinado a erradicar a pobreza e a marginalização e reduzir as desigualdades sociais e regionais.

\section{REFERÊNCIAS DAS FONTES CITADAS}

BUENO, José Antonio Pimenta Direito Público Brasileiro e Análise da Constituição do Império Univ. Brasília, 1978.

CAVALCANTI, Themistocles Brandão. A Constituição Federal comentada. 2. ed. Rio de Janeiro: Konfino, 1952.

FIORILLO, Celso Antonio Pacheco. Curso de Direito Ambiental Brasileiro, 19a edição, revista, ampliada e atualizada São Paulo: Saraiva, 2019; 
FIORILLO, Celso Antonio Pacheco; FERREIRA, Renata Marques. Curso de direito da energia - Tutela jurídica da água, do petróleo, do biocombustível, dos combustíveis nucleares, do vento e do sol. $3^{a}$ edição, São Paulo: Ed. Saraiva, 2015.

LEWANDOWSKI, Enrique Ricardo Globalização, Regionalização e Soberania São Paulo: Editora Juarez de Oliveira, 2004.

MATEUCCI, Nicola Dicionário de política I Norberto Bobbio, Nicola Matteucci e Gianfranco Pasquino; trad. Carmen C, Varriale et al.; coord. trad. João Ferreira; rev. geral João Ferreira e Luis Guerreiro Pinto Cacais. - Brasília: Editora Universidade de Brasília, 1 la ed., 1998.

MORAES, Alexandre Direito Constitucional. 27ª edição São Paulo: Atlas,2011.

PONTES DE MIRANDA, Francisco Cavalcanti. Comentários à Constituição de 1967 com a emenda n. 1 de 1969. 3. ed. Rio de Janeiro: Forense, 1987.

SARDENBERG, Ronaldo Mota Ordenação territorial e desenvolvimento sustentável, Folha de S. Paulo, caderno I, p. 3, 24 abr. 1995.

SILVA, José Afonso Comentário Contextual à Constituição. 7. ed. São Paulo: Malheiros,2010.

TÁVORA, Juarez. Petróleo para o Brasil. Rio de Janeiro: José Olympio, 1955.

TOLMASQUIM, Mauricio T.; GUERREIRO, Amílcar; GORINI, Ricardo Matriz energética brasileira: uma prospectiva Novos estud. - CEBRAP nº.79 São Paulo Nov. 2007.

VAITSMAN, Maurício. O petróleo no Império e na República. 2. ed. Rio de Janeiro: Interciência, 2001.

\section{RECEBIDO EM: 17/10/2019}

APROVADO EM: 26/11/2019 